\title{
ARTICLE
}

\section{Survival of rehabilitated and released red-tailed hawks (Buteo jamaicensis)}

\author{
Jacqueline E. Sandberg ${ }^{1}$, Timothy R. Van deelen² \& Mark E. Berres ${ }^{2}$ \\ 'Department of Forest and Wildlife Ecology, Dane County Humane Society's Wildlife Center, Madison, WI, USA; \\ ${ }^{2}$ Department of Genetics, University of Wisconsin, Madison, WI, USA
}

\begin{abstract}
Wildlife rehabilitation provides responsible care for sick, injured or orphaned wild animals with the goal of releasing fully recovered individuals back into the environment. Post-release survival data for these animals remain sparse but necessary to measure and assess the impact of wildlife rehabilitation as a conservation strategy. This study used national banding data to quantitatively compare annual survival of wild-caught (non-rehabilitated) and rehabilitated red-tailed hawks (Buteo jamaicensis). In addition, 13 rehabilitated and released red-tailed hawks from Dane County Humane Society's Wildlife Center (DCHS, Madison, WI) were monitored using radio telemetry. Annual survival of rehabilitated and radio-tagged red-tailed hawks from DCHS was 36\% over 85 weeks of monitoring. Nationally, wild red-tailed hawk annual survival (0.777; $95 \%$ CI $[0.768,0.777])$ was largely equivalent to estimates reported in other published studies. These estimates reflect average survival over 40 years in a fully time-dependent model (variance component estimated using the Delta Method; Powell 2007). Rehabilitated red-tailed hawks had an annual survival of 0.549 (95\% CI: $0.523,0.575]$ ) over 43 years. These values reflect modelaveraged estimates from time-independent survival models (recovery was time dependent) that were equivalent in terms of likelihood (Brownie $=$ Seber $=$ $\left.\mathrm{w}_{\mathrm{i}}=0.50\right)$. Consequently, survival of rehabilitated red-tailed hawks was approximately $22 \%$ lower than wild-caught individuals. Furthermore, young (hatch-year) red-tailed hawks experienced increased mortality (34\%) relative to those rehabilitated as adults $(0.255 ; 95 \%$ CI $[0.199,0.321]$ versus 0.598 ; $95 \%$ CI $[0.571,0.624]$, respectfully). The results of this study demonstrate the need for additional post-release monitoring and may guide future management decisions regarding wildlife rehabilitative criteria, practice and viability.
\end{abstract}

\section{BIO}

Jacqueline E. Sandberg is the Wildlife Training Supervisor of Dane County Humane Society's Wildlife Center in Madison, WI, and has been a member of NWRA since 2012. Jacqueline performed this survival study for her M.S. degree in Conservation Biology and Sustainable Development under the direction of Dr Mark Berres and Dr Tim Van Deelen at the University of Wisconsin-Madison.

Mark Berres received a PhD in zoology at the University of Wisconsin-Madison in 2003 and conducts bioinformatics research in the Advanced Genome Analysis Resource Center at the University of Wisconsin-Madison Biotechnology Center.

Tim Van Deelen received a PhD in Wildlife Ecology at Michigan State University in 1995 and is currently a professor specialized in wildlife management and population dynamics in the Department of Forest and Wildlife Ecology.

\section{Introduction}

Wildlife rehabilitation provides responsible care for sick, injured or orphaned wild animals with the ultimate goal of releasing fully recovered individuals back into the

\section{Keywords}

Red-tailed hawk; wildlife rehabilitation; survival; mark-recapture; telemetry

\section{Correspondence}

Jacqueline E. Sandberg, Dane County Humane Society, 5132 Voges Rd. Madison WI 53718, 608-287-3238,

Email: jsandberg@giveshelter.org

\section{Abbreviations}

AICc: Akiake's second order Information Criteria

BBL: Bird Banding Laboratory

CJS: Cormack-Jolly-Seber

ICF: International Crane Foundation IWRC: International Wildlife Rehabilitation Council

NWRA: National Wildlife Rehabilitators

Association

PCR: Polymerase Chain Reaction

RTHA: Rehabilitated red-tailed hawk

USGS: United States Geological Survey's WWRA: Wisconsin Wildlife Rehabilitators Association

Dates

Accepted: 20 November 2019

Published: 25 January 2022 
relative to patient survival (Duke et al. 1981) or mortality (Punch 2001) exist. However, the available literature is insufficient in scope, particularly when considering how crucial this information is to properly assessing the efficacy of wildlife rehabilitation (Tristan 2001). Absence of post-release information ultimately prevents wildlife rehabilitators and veterinarians from determining the full success of their efforts (Reed 1976; Martell et al. 1991).

Evaluating the long-term effects of rehabilitative practices on outcomes may provide evidence to support or refute the prevailing belief that recovered individuals reintegrate successfully back into the wild population. In general, this may mean the ability to obtain natural food sources, select mates, reproduce and avert threats to safety, in other words, functioning to expectations consistent with the species' life history and maintaining a reasonable life expectancy after release. Direct information is needed to assess these criteria, such as that obtained from mark-recapture or band return studies, which can then be used to objectively compare survivorship of rehabilitated individuals. Analytical methods for studies of marked individuals allow scientists to estimate parameters such as mortality rates, home range and population size (Bildstein \& Peterjohn 2012; Bobowski 2013). Availability of high-quality datasets with large numbers of marked individuals is vital to producing reliable estimates in any mark-recapture survival study (Johnson 1974), so marking and tracking adequate numbers of animals is required to determine if the outcome of rehabilitation efforts is successful (Fajardo et al. 2000; Martell et al. 2000).

At least 250 wildlife rehabilitation facilities in North America rehabilitate predatory birds of prey in the Orders Falconiiformes, Accipitriformes and Strigiformes (Martell et al. 1991; Heintzelman 2004; Joosten \& Moore 2004). Duke et al. (1981) estimated that up to 7,000 birds of prey could be admitted to North American wildlife rehabilitation centres annually, offering a potential for increased bird banding and survival studies. Birds of prey are good scientific models to assess wildlife rehabilitation efforts through banding because of their importance in ecological systems, vulnerability to anthropogenic injury or mortality (Cherkassky 2011; Molina-Lopez et al. 2011; Battistone 2012) and high abundance of biological information available in scientific literature (Bildstein \& Peterjohn 2012). Additionally, hunting behaviours, reproductive strategies, migration and ecology can be generally compared between similar Buteo species (Newton 1979; Sullivan 1995; Amaral et al. 2009). Using common bird of prey species as primary study subjects may aid those of conservation concern by offering essential methods and experience for continued research (Duke et al. 1981).
Red-tailed hawks (Buteo jamaicensis) are one of the most abundant and well-documented bird of prey species world-wide, and their population size is estimated between 600,000 and 1 million individuals in North America (Fitch et al. 1946; Luttich et al. 1971; Gates 1972; Heintzelmen 2004; Bloom 201 1; Schoenebeck et al. 2014). Substantial amounts of banding data from red-tailed hawks have been collected by the United States Geological Survey's (USGS) Patuxent Wildlife Research Center's Bird Banding Laboratory (BBL; Laurel, Maryland) and are publicly available via the USGS website. Over 196,000 wild red-tailed hawks have been banded since 1960 in the United States and Canada, with an average of 3.6\% of those bands being returned annually (USGS 2013). Additionally, 11,468 rehabilitated red-tailed hawks have been banded and released in the United States or Canada, with about $10 \%$, or 1,138, of those red-tailed hawks having been reported back to BBL since 1957 (USGS 2013).

Advantageously, this study incorporates both a large national banding dataset and a cohort of locally rehabilitated, released and monitored (radio-telemetry) individuals to evaluate annual survival of wild-caught and rehabilitated red-tailed hawks through mark-recapture analysis. The purpose of this research was to collect, analyse and disseminate more post-release survival data on rehabilitated and released red-tailed hawks. More broadly, the results of this study may help inform wildlife rehabilitators and veterinarians in their efforts to gauge the effectiveness of particular treatment options, surgical techniques and rehabilitation methods on other large birds of prey, thereby improving rehabilitative practices and maximizing the success of post-release individuals.

\section{Materials and methods}

Mark-recapture data were obtained from two primary sources: (1) approximately 43 years of national band returns from the USGS Patuxent Wildlife Research Center's Bird Banding Laboratory and (2) 13 rehabilitated red-tailed hawks from Dane County Humane Society's Wildlife Center (DCHS; Madison, Wisconsin) that were released and monitored via radio-telemetry in south central Wisconsin (2014-2016).

First, a mark-recapture survival analysis was conducted using the national band return data to compare survival rates of wild-caught and rehabilitated red-tailed hawks. Next, a supplementary known-fate investigation was performed to determine if the annual survival of 13 rehabilitated and released red-tailed hawks from DCHS differed from estimates calculated from national band returns. Last, post-release survival time and causes of mortality were summarized from rehabilitated red-tailed hawks national band return encounter histories. 
The following hypotheses were tested: (1) rehabilitated red-tailed hawk annual survival does not differ from that of wild-caught red-tailed hawk survival, (2) adult red-tailed hawk survival does differ from young (hatch-year) redtailed hawk survival, and (3) red-tailed hawk annual survival does not differ between summer and winter seasons (March through November and December through February, respectively).

\section{Dead recovery modelling}

Band recoveries from dead and reported red-tailed hawks (6,225 wild-caught from 1974 to 2013 and 771 rehabilitated from 1970 to 2013) in the United States and Canada were used in a mark-recapture analysis to determine if annual survival rates of rehabilitated red-tailed hawks were significantly different from those in natural populations. Red-tailed hawks age stratification comprised of wild-caught: 1,625 adults and 4,630 young (hatch-year bird) and rehabilitated: 559 adults, 204 young and 8 of unknown age (USGS 2013).

Annual survival rates were calculated using two parameterizations for "dead" recovery models in Program MARK: White et al 2001; Brownie et al. (1985) and Seber (1970). Additional constraints were added to both parameterizations from the Cormack-Jolly-Seber (CJS) model to assess whether apparent survival $(\phi)$ and recovery rates $(p)$ were time dependent (t) or fixed (.). All possible combinations of time dependence models from CJS were tested among three categories of age classification: (1) no age structure (a combination of all ages: adults, young and unknown), (2) young only and (3) adults only. Further constraints were added to models that combined young and adult redtailed hawks band returns to reflect the one-time transformation of a young (hatch-year bird) into an adult over time (Brownie et al. 1986; Lebreton et al. 1992).

Mark-recapture models reflecting distinct age- and time-dependence factors among survival and recovery parameters were compared using Akiake's second-order Information Criteria (AICc). A cut-off of $\triangle \mathrm{AICc}>7$ was used to indicate strong evidence of a difference between two separate models. Values of $\Delta \mathrm{AICc}<2$ were interpreted to indicate that the two models were of equal weight (Cooch \& White 2012). In cases where numerical convergence failed, alternative link functions (e.g., sine, $\log$ or $-\log -\log$ ) were tested to better fit the data (White $\delta$ Burnham 1999).

Wild red-tailed hawk seasonal annual survival calculations contained two additional years of banding data (2014-2015; USGS 2013). Deceased band returns of winter releases were separated from summer releases based on red-tailed hawk migratory periods and breeding cycles. Winter months were restricted to December,
January and February of each year to reflect red-tailed hawk non-breeding and post-migration time periods. Summer months were restricted from March through November to include periods of prolonged fall migration. This allowed for a comparison to other studies that showed no decrease in young (hatch-year) red-tailed hawk mortality after August 1st (Newton 1979).

\section{Causes of mortality and survival time}

Rehabilitated red-tailed hawks $(n=847)$ were reported "dead" from original USGS datasets of 1,138 total rehabilitated red-tailed hawk encounters (USGS 2013). All entries listed with unknown statuses or undetermined recovery dates were removed, and "Present Condition" and "How Obtained" codes were used to summarize causes of rehabilitated red-tailed hawk mortality. A total of 777 encounter histories were usable to summarize post-release mortality and survival times. Causes of mortality and survival time of 6,225 wild-caught, banded and deceased red-tailed hawks were not summarized in this study.

\section{Known-fate modelling}

Thirteen rehabilitated red-tailed hawks from DCHS were available for post-release monitoring and represented common categorizations of injury in wildlife rehabilitation at admission, which included: broken bones $(n=5)$, severe physical injury (spinal, soft tissue or ocular trauma; $n=5)$, and emaciation $(n=3)$. Age was determined by plumage characteristics (6 young and 7 adults), and sex was determined by polymerase chain reaction (PCR; 10 females and 3 males) of DNA extracted and purified from blood (Fridolfsson \& Ellegren 1999; Donohue \& Dufty 2006).

A 1,140 transponders (Advanced Telemetery Solutions, Isanti, MN) weighing $22 \mathrm{~g}$ were attached to anesthetized, rehabilitated red-tailed hawks designated for release one week prior to discharge. In each case, the weight of the transpoder was less than $2 \%$ body weight as recommended by Kenward (2001) and Hamilton et al. (1988). Red-tailed hawk adults were released at or near their point of origin from admission. Young (hatch-year) red-tailed hawks were released using a modified hacking process in Cooksville, WI, for 5-7 days prior to release. The modified hacking process involved moving the birds to an open flight enclosure, meaning that they had the ability to depart at any time, where they were provided with supplemental food daily until they left. Once released, birds were located daily using both an omnidirectional, land-use vehicle antennae and yagi 3-element folding antenna with receivers (2-6 mile range). Visual confirmation was attemped during every locating effort. 
If unsuccessful, at least three independent coordination attempts were made to establish occupancy in a specific area (Lenth 1981). Tracking ceased upon signal loss (i.e., birds were censored from the study) or when a mortality signal was identified.

Survival rates of the 13 rehabilitated and released red-tailed hawks from DCHS were calculated by using the Kaplan-Meier known-fate model (Pollock's staggered entry design; Pollock et al. 1989). Time points were recorded as the number of weeks past release and written in Live, Dead, Live, Dead (LDLD) format, and censored birds were recorded appropriately (Pollock et al. 1989; Cooch \& White 2012). Red-tailed hawks that survived past the first year of study ( 52 weeks) were right censored, reentering the population at the start of year two (Jackson 2011). The estimated annual survival rate of 13
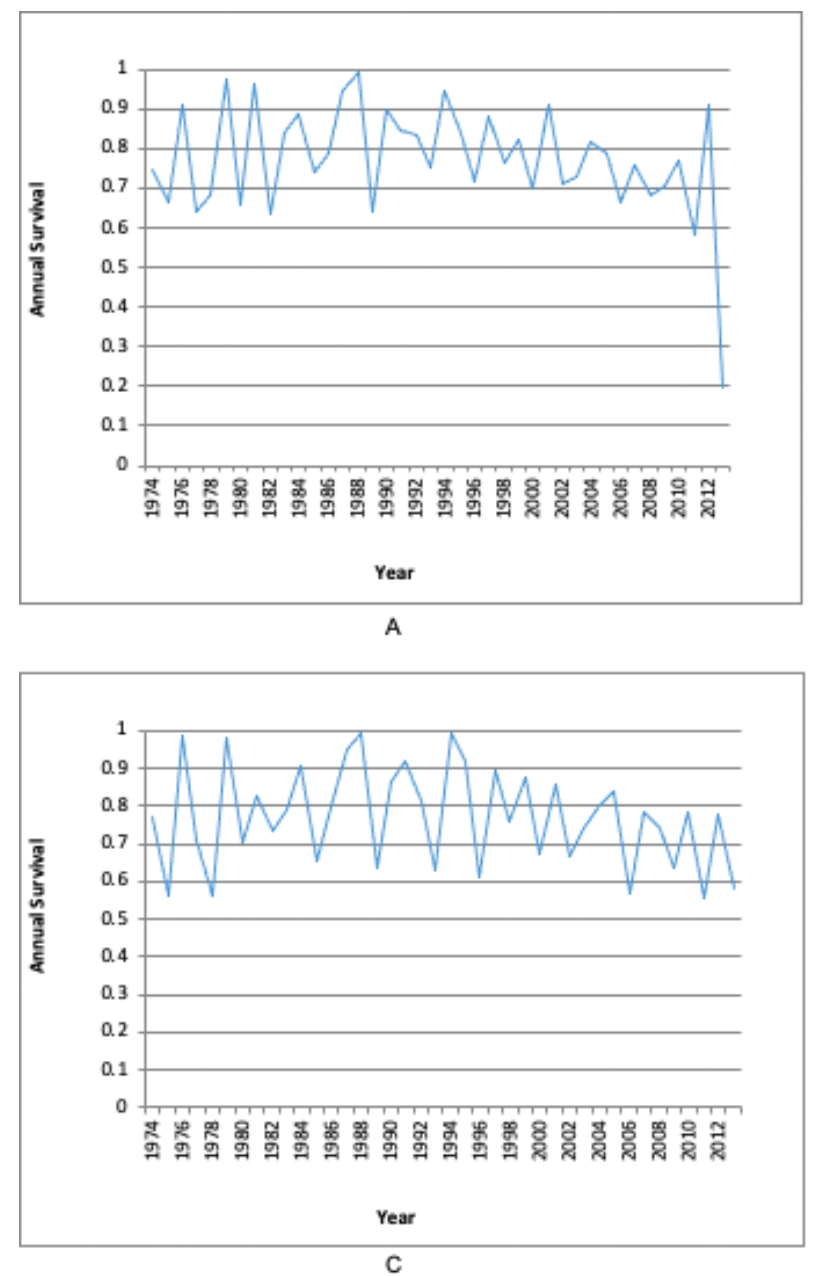

rehabilitated red-tailed hawks from DCHS was then compared to results from the aforementioned rehabilitated, banded and retrieved red-tailed hawks from the USGS between 1970 and 2013 using a simple, two-tailed z-test (Pollock et al. 1989).

\section{Results}

\section{Wild red-tailed hawks}

Optimal survival models based on AICc criteria reflect time-dependent survival (Figure $1 \mathrm{a}-\mathrm{d}$ ).

Annual survival of wild red-tailed hawks (1974-2013) estimated by using the Seber (1970) parameterization in Program MARKl (White et al. 2001). In the Seber (1970) survival model, with Cormack-Jolly-Seber (CJS)
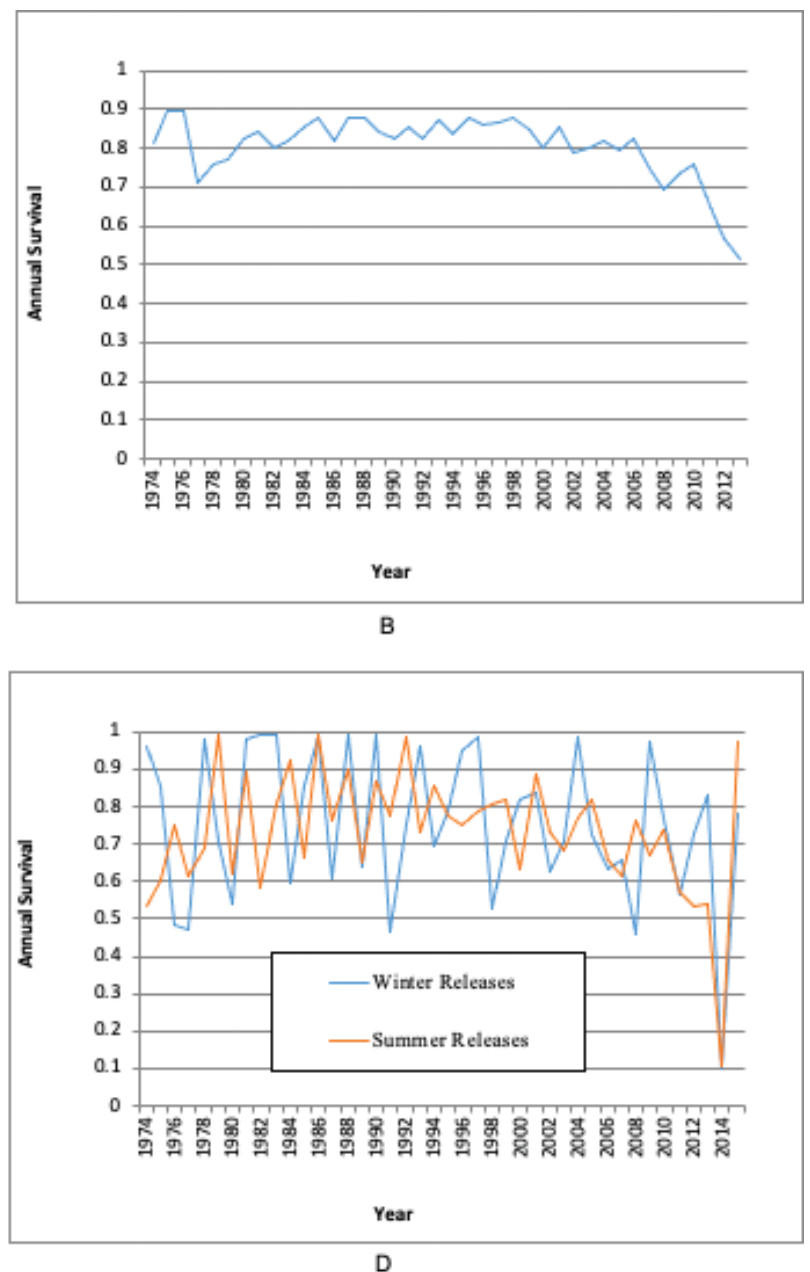

Figure 1 a-d. Annual survival of wild red-tailed hawks (1974-2013) and seasonal annual survival rates (1974-2015) estimated by using the Seber (1970) parameterization in Program MARK. Three categories of age structure are compared: no age structure (combination of adults, young and unknown ages), adults only and young only. (A) Time-dependent annual survival estimates of wild red-tailed hawks without age structure, (B) time-dependent annual survival estimates of wild red-tailed hawks (adults only), (C) time-dependent annual survival estimates of wild red-tailed hawks (young only) and (D) time-dependent seasonal annual survival estimates of wild red-tailed hawks 1974-2015 (no age structure was incorporated into this model). 
Table 1 Annual survival of wild red-tailed hawks (1974-2013).

\begin{tabular}{lcccccc}
\hline Age structure & $\begin{array}{c}\text { Strongest survival } \\
\text { model }\end{array}$ & $\begin{array}{c}\text { No. estimable } \\
\text { parameters }\end{array}$ & $\begin{array}{c}\text { Survival } \\
\text { estimate }(\mathrm{S})\end{array}$ & $\begin{array}{c}\text { Recovery estimate } \\
(\mathrm{r})\end{array}$ & AICc & AIC weight \\
\hline None & $\mathrm{s}(\mathrm{t}) \mathrm{r}(\mathrm{t})$ & 78 & 0.77 & 0.08 & 81510.7 & 0.73 \\
Adults only & $\mathrm{s}(\mathrm{t}) \mathrm{r}(\mathrm{)})$ & 41 & 0.80 & 0.03 & 21561.2 & 0.96 \\
Young only & $\mathrm{s}(\mathrm{t}) \mathrm{r}(\mathrm{t})$ & 76 & 0.77 & 0.12 & 59922.4 & 1,622 \\
\hline
\end{tabular}

Table 2 Annual survival of rehabilitated red-tailed hawks (1970-2013).

\begin{tabular}{|c|c|c|c|c|c|c|c|c|}
\hline Age structure & $\begin{array}{c}\text { Strongest } \\
\text { survival model }\end{array}$ & $\begin{array}{c}\text { No. estimable } \\
\text { parameters }\end{array}$ & \multicolumn{2}{|c|}{ Survival estimate (S) } & $\begin{array}{c}\text { Recovery } \\
\text { estimate (r) }\end{array}$ & $\mathrm{AICC}$ & $\begin{array}{c}\text { AIC } \\
\text { weight }\end{array}$ & $n^{2}$ \\
\hline None & $s() f.(t)$ & 45 & \multicolumn{2}{|c|}{0.55} & 0.04 & $7,866.59$ & 0.5 & 771 \\
\hline Young only & $\mathrm{s}(\mathrm{a} 2.1.) \mathrm{r}()$. & 3 & $S_{\text {(young) }}=0.26$ & $S_{\text {(adult) }}=0.66$ & 0.07 & $1,889.08$ & 0.1 & 204 \\
\hline Mixed & $\mathrm{Sg} \mathrm{g}^{\star}(\mathrm{ta} 2-. /)-.. . \mathrm{r}()$. & 4 & $S_{\text {(young) }}=0.26$ & $S_{(\text {adult) }}=0.60$ & 0.07 & $7,754.93$ & 0.72 & 204 (young) 559(adults) \\
\hline
\end{tabular}

constraints, $\mathrm{f}=\mathrm{S}$, for survival, and $\mathrm{p}=\mathrm{r}$, for recovery. Three categories of age structure are compared: no age structure (combination of adults, young and unknown ages), adults only and young only. $n=$ number of band returns used in each survival estimate; $(\mathrm{t})=$ time dependent survival; $($.$) = fixed survival.$

\section{Rehabilitated red-tailed hawks}

The mixed model (Table 2 ) reflects the AICc-optimal model for rehabilitated red-tailed hawks. This model reports fixed and identical recovery parameters I with constant young and adult survival (S) through time (i.e., no time dependence between cohorts banded annually from 1970 to 2013). Young (hatch-year) birds are banded at time $n=1$ and are considered adults the year after spanning through the rest of their lifetimes (no time dependence in annual survival). Results from this model are displayed graphically in Figure 2.

Rehabilitated red-tailed hawk annual survival (19702013) estimated by using the Seber (1970) and Brownie et al. (1985) parameterizations in Program MARK1. In the Seber (1970) survival model, with Cormack-JollySeber (CJS) constraints, $\mathrm{f}=\mathrm{S}$, for survival, and $\mathrm{p}=\mathrm{r}$, for recovery; in the Brownie et al. (1985) survival model, $\mathrm{f}=\mathrm{S}$, for survival, and $\mathrm{p}=\mathrm{f}$, for recovery. Three categories of age structure are compared: no age structure (combination of adults, young and unknown ages), adults only and young only. Mixed age structure includes returns from adults, young and unknown ages, but estimates of two age categories are displayed in the table (young only and adults only). $n=$ number of band returns used in each survival estimate, $(\mathrm{t})=$ time dependent survival, (.) = fixed survival, (a2) = age class, with year 2 being the maximum age and $(\mathrm{g})=$ groups (individuals marked as young or adults).

\section{USGS encounter history data}

USGS banding reports (1957-2013) consisted of 1,138 rehabilitated and released red-tailed hawks, of which 847 individuals were reported dead (USGS "Present Condition" codes 3, 4 and 5), 216 individuals were reported as sighted alive (USGS "Present Condition" codes 6-14) and 32 were reported in an unknown present condition (codes 0, 1 and 2; USGS 2013). After subtracting duplicate entries, the average post-release survival length of rehabilitated red-tailed hawks reported deceased was $1.52( \pm 0.1)$ years $(n=777)$. A full trajectory of post-release rehabilitation survival times (range 0-24 years) is shown in Figure 3 (USGS 2013). After removing all undetermined recovery dates $(n=70)$, a total of $496(64 \%)$ rehabilitated red-tailed hawks were reported dead within 52 weeks post-release from rehabilitation. Another 110 (14\%) lived between one and two years post-release from rehabilitation. The top five explanations for reporting a band from a rehabilitated red-tailed hawk $(n=847)$ included 488 undetermined, 109 found dead or injured on a highway, 83 caught or killed by being struck by an automobile, 64 caught due to injury and 20 confirmed shot.

\section{Known-fate red-tailed hawks}

Thirteen rehabilitated and released red-tailed hawks were monitored between 5 August 2014 and 21 March 2016 (85 weeks). A total of 1,603 locations were recorded. Survival time ranged from 1 day to 482 days post-release $(\bar{x}=147$ \pm 81 days), and overall annual survival was estimated to be $36 \%$ (Figure 4 ). At least two out of 13 rehabilitated red-tailed hawks $(15 \%)$ tracked in this study between 2014 and 2016 lived to at least one-year post-release. Six of 13 rehabilitated red-tailed hawks $(46 \%)$ tracked in this 


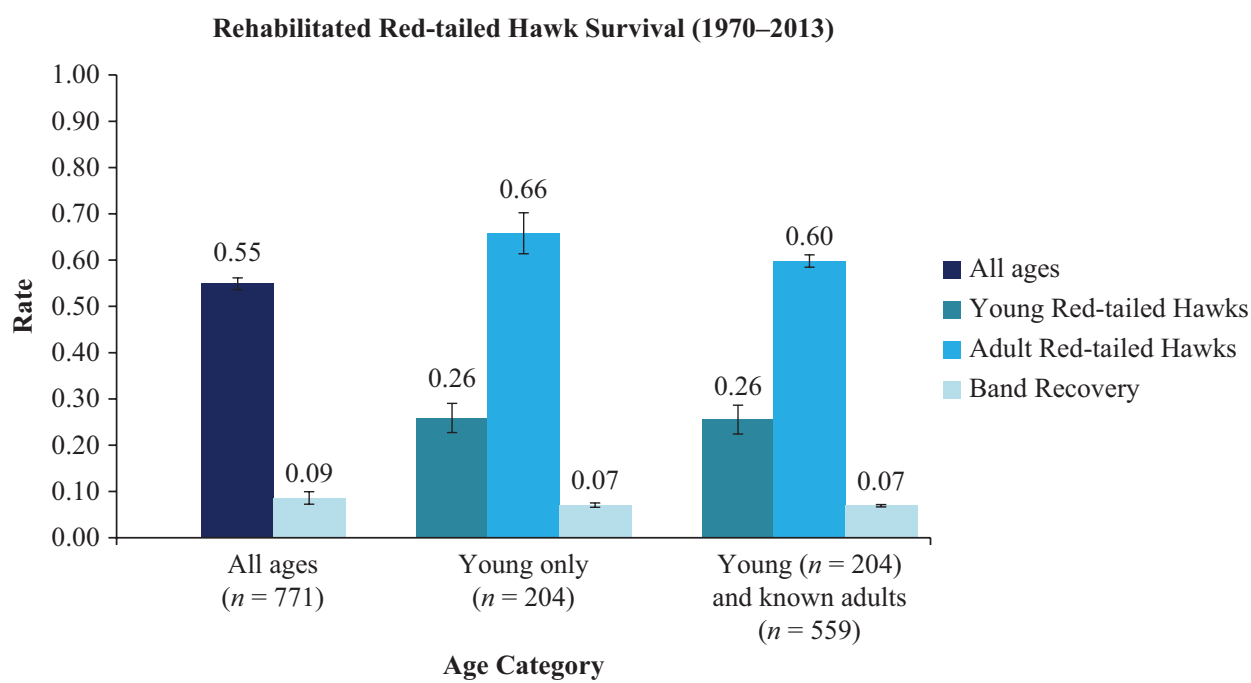

Figure 2. Annual survival and recovery for three age categories of rehabilitated red-tailed hawks were estimated by the Seber (1970) and Brownie et al. (1985) parameterizations in Program MARK. Age categories include no age structure (combination of adults, young and unknown ages), young only and adults only.

Rehabilitated Red-tailed Hawk Post-release Survival Time (1957-2013)

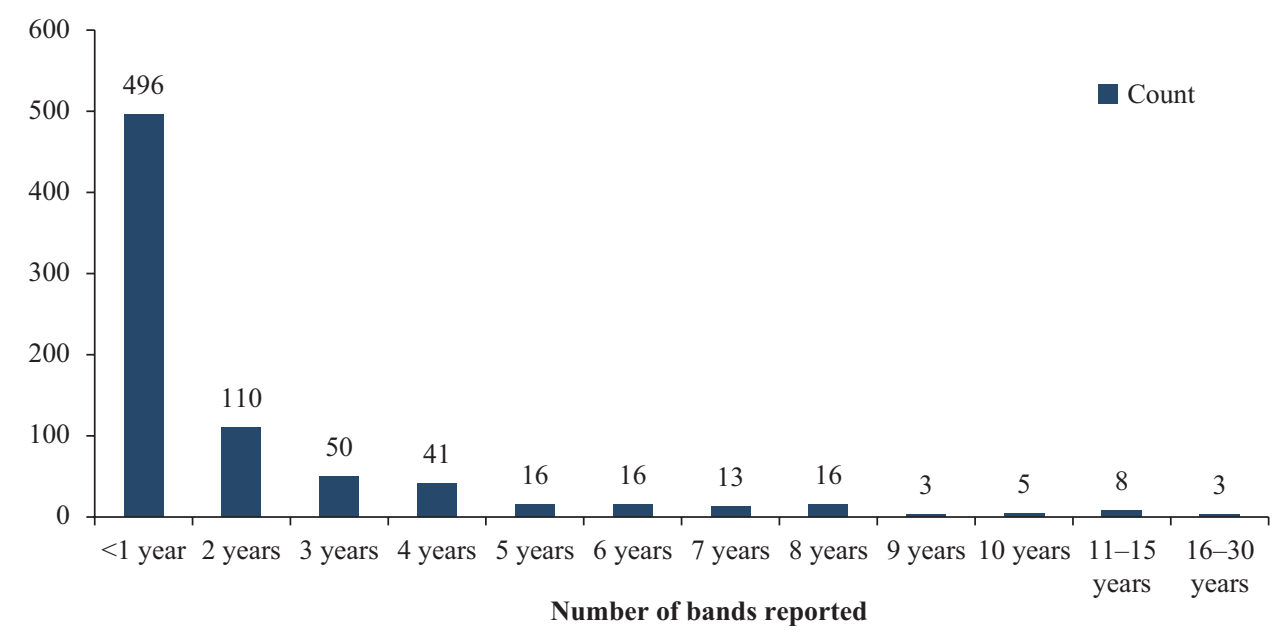

Figure 3. Rehabilitated red-tailed hawk (RTHA) post-release survival time. Banding data were obtained from USGS bird banding laboratory over a period of 1957-2013. All entries listed with unknown present condition statuses or undetermined recovery dates were censored from the datasets. A total of 777 encounter histories were useable. Average post-release survival length of rehabilitated RTHA reported deceased was $1.52( \pm 0.1)$ years.

study were censored between 2014 and 2016 and may still be alive. Four birds died during the study period, and one was readmitted (later to be euthanized), therefore resulting in a $38 \%$ mortality rate.

Statistically comparing the overall average survival of 13 rehabilitated red-tailed hawks from DCHS $(0.357$; $95 \%$ CI $[0.106,0.608])$ to annual survival estimates from national banding data $(0.549 ; 95 \%$ CI: 0.523 , $0.575])$ resulted in no significant difference $(p=0.59$; Pollock et al. 1989).

\section{Discussion}

\section{Survival rate}

Annual survival calculated from national banding data of wild-caught red-tailed hawks (1974-2013) was largely equivelent to estimates reported in other published studies (Table 3).

Rehabilitated red-tailed hawks annual survival from 1970 to 2013, without any population age structure information, was lower than those that are wild-caught 
DCHS Rehabilitated Red-tailed Hawk Survival (August 2014-March 2015)

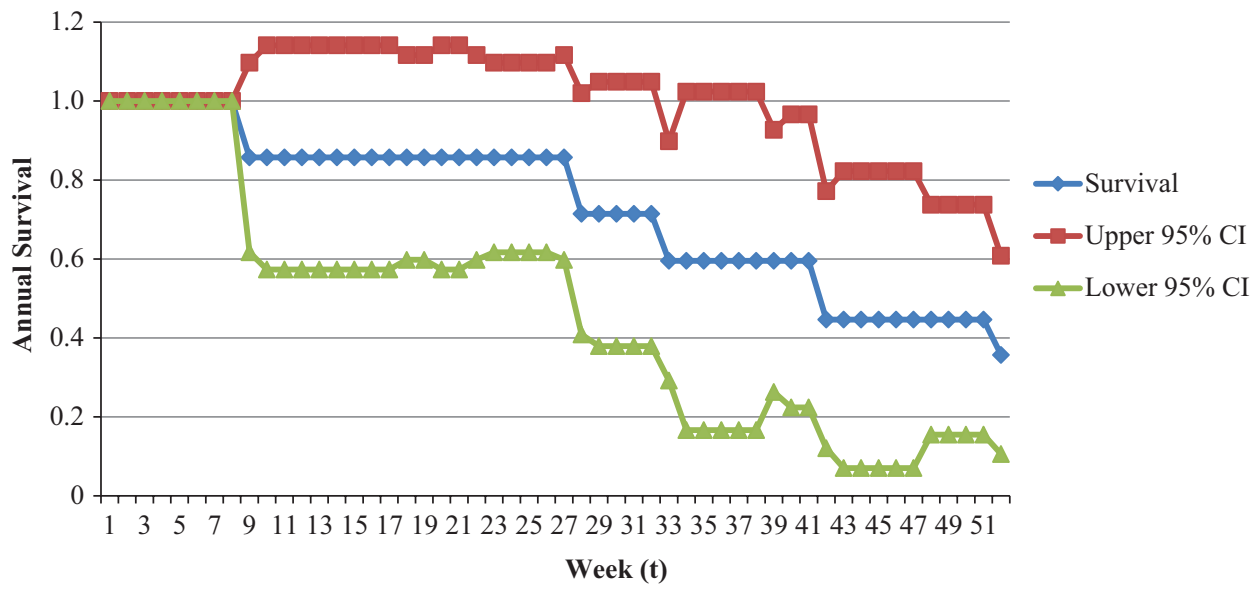

Figure 4. The Kaplan-Meier known fate model (Pollock's Staggered Entry design) to estimate annual survival of 13 rehabilitated and released red-tailed hawks from Dane County Humane Society's Wildlife Center (DCHS, Madison, WI). The probability of detection begins at a maximum of 1.0, and the survival estimate drops during each interval that an individual is confirmed deceased. RTHA that survived past the first year of study (52 weeks) were right censored, re-entering the population at the start of year two.

Table $\mathbf{3}$ Wild bird of prey species and their estimated survival rates adapted from Briggs 2007

\begin{tabular}{llcl}
\hline Species & \multicolumn{1}{c}{ Common name } & $\begin{array}{c}\text { Annual adult } \\
\text { survival estimate }\end{array}$ & \multicolumn{1}{c}{ Source } \\
\hline Buteo regalis & Ferruginous Hawk & $75 \%$ & Woffinden \& Murphey (1989) \\
Buteo solitarius & Hawaiian Hawk & $91.7 \%$ & Griffin (1985) \\
Parabuteo unicinctus & Harris's Hawk & $81.7 \%$ & Bednarz (1995) \\
Buteo lineatus & Red-shouldered Hawk & $70.3 \%$ & Henny \& Wight (1972) \\
Buteo buteo & Common Buzzard & $40-75 \%$ & Kruger et al. (2001) \\
Buteo swainsoni & Swainson's Hawk & $83-88 \%$ & Briggs (2007) \\
Buteo jamaciensis & Red-tailed Hawks & $80 \%$ & Henny \& Wight (1972) \\
& & $80 \%$ & Kerlinger (2005) \\
& & $\mathbf{8 0 \%}$ & Edmunds (2016) \\
\hline
\end{tabular}

Table 4 Red-tailed Hawk (Buteo jamaicensis) estimated survival or mortality rates from various cited sources.

\begin{tabular}{|c|c|c|c|c|}
\hline Sample size & Study dates & Age & Survival or mortality estimate & Source \\
\hline$n=38$ & 1941 & Nestling & $40 \%$ (mortality estimate) & Fitch et al. (1946) \\
\hline$n=117$ & 1951 & Juvenile (<1 year) & $54 \%$ (mortality estimate) & Battistone (2012); Henny \& Wight (1970) \\
\hline$n=135$ & 1966-1969 & $\begin{array}{l}\text { Nestling }(<4 \text { weeks }) \\
\text { Juvenile }(<1 \text { year })\end{array}$ & $\begin{array}{l}11 \% \text { (mortality estimate) } \\
51-62 \% \text { (mortality estimate) }\end{array}$ & Luttich et al. (1971, Table 6) \\
\hline $\begin{array}{l}n=29 \\
n=117\end{array}$ & 1926-1964 & $\begin{array}{l}\text { Adult } \\
\text { Juvenile ( }<1 \text { year) }\end{array}$ & $\begin{array}{l}20-26 \% \text { (mortality estimate) } \\
62.4-66.7 \% \text { (mortality estimate) }\end{array}$ & Henny \& Wight (1972) \\
\hline$n=137$ & 1971-1972 & $\begin{array}{l}\text { Juvenile } \\
\text { Nestling (pre-fledging) }\end{array}$ & $\begin{array}{l}50 \% \text { fledged (survival estimate) } \\
8-11 \% \text { (mortality estimate) }\end{array}$ & Johnson (1975) \\
\hline$n=20$ & & Adult & $80 \%$ (survival estimate) & Kerlinger (2005) \\
\hline$n=1,622$ & 1974-2013 & Adult & $80 \%$ (survival estimate) & Edmunds (2016) \\
\hline
\end{tabular}


and banded by a difference of approximately $22 \%$. Young red-tailed hawks experienced increased mortality earlier than those rehabilitated as adults by a difference of approximately $34 \%$. Time of release did not markedly affect seasonal survival of rehabilitated or wild red-tailed hawks. Individuals released in winter (January, February or December) compared to those released in spring, summer or fall (March-November) were very similar (56-54\% and $75-73 \%$, respectively).

The survival rates presented in this study were established by comparing two different dead recovery models in Program Mark: the Seber (1970) model and the Brownie et al. (1985) model. The strongest survival models based on AICc criteria were uniformly supported by the Seber (1970) parameterization for wild red-tailed hawks, but it only supported two out of three top models for rehabilitated red-tailed hawks. The Brownie et al. (1985) model was originally designed to calculate annual survival (S) based on two forms of mortality: killed by hunting pressure $(\mathrm{K})$ or death by natural causes (1-S-K). Hunting pressure (K) could be defined as mortalities directly caused by human influence, as many red-tailed hawks are found dead due to vehicular impacts, poisoning or illegal shooting, among other reasons (USGS 2013). Therefore, the Brownie et al. (1985) method may be a better fit model for calculating annual survival rates of rehabilitated, banded and released red-tailed hawks in the future based on increasing rates of anthropogenic injury and mortality (i.e., hunting pressure).

Low first-year survival has been documented in wild red-tailed hawks, perhaps due to higher mortality risk associated with long-distance dispersal after fledging from the nest (Bloom et al. 2011; Battistone 2012; Perrins \& Birkhead 1983). Lower annual survival for hatch-year rehabilitated red-tailed hawks was therefore expected, yet it was $51 \%$ lower than the rate calculated from national banding data for hatch-year, wild-caught red-tailed hawks. The annual survival rate of 13 rehabilitated and released red-tailed hawks from DCHS was lower than the national average for all deceased band reports of rehabilitated red-tailed hawks banded between 1970 and 2013.

However, 13 birds is a low sample size, $46 \%$ of birds were hatch-year, and six birds were censored from the study. Due to the small sample size of radio-tracked individuals $(n<25)$, statistically comparing the survival results from known-fate modelling to the survival rates estimated using the dead-recovery modelling from national banding data would not allow for relevant disparities to be detected (Buderman et al. 2014). Furthermore, traditional model assumptions include representation within the same study area for more accurate comparison (Nasution et al. 2001). However, in a broad context, using simple statistical methods, the overall survival rate of rehabilitated red-tailed hawks of all ages $(n=13)$ from DCHS is lower than national estimates by a difference of $19 \%$ and is considered not significant $(p>0.05$ (two-tailed)).

These differences may suggest that reduced survival rates of rehabilitated red-tailed hawks are associated with age (hatch-year birds vs. adults, similarly described by Perrins \& Birkhead 1983), geographic location, differences in rehabilitation or veterinary methods, or injury type and severity. Additional known-fate studies using large sample sizes of rehabilitated and released red-tailed hawks would offer auxiliary data to determine if these differences exist and to allow for more precise annual survival estimates.

\section{Survival time}

This study reports low post-release survival length of rehabilitated red-tailed hawks (1.52 $( \pm 0.1)$ years, $n=777)$. Previous studies have additionally concluded that low survival time is experienced by rehabilitated and released birds of prey. Martell et al. (2000) found that 50\% of band reports came back as mortalities within 6 months post-release ( $n=135 ; n=18$ red-tailed hawks), but no cause of death information was offered. Other studies of Falconiformes reported over $50 \%$ of individuals surviving at least 2-6 weeks post-release, with adverse weather or emaciation being likely causes of mortality (Duke et al. 1981; Hamilton et al. 1988). Variation in mortality rates could suggest species-specific differences in rehabilitative or veterinary practices, choice of release site and time of year factors. Presently, a time frame of 6 weeks is the only criterion that has been used to describe the fitness or success of rehabilitated birds of prey post-release because it is estimated to be the maximum length an ill-equipped bird can survive in the wild before dying of starvation (Duke et al. 1981; Martell et al. 2000). The sample sizes and length of time monitoring post-release from these studies were small but, nonetheless, offered preliminary evidence of survival for post-release rehabilitated birds of prey.

This study reports $64 \%$ of rehabilitated red-tailed hawks reported dead within 52 weeks post-release and only 14\% living between one and two years post-release $(n=847)$. The combination of those two statistics encompasses over $75 \%$ of rehabilitated and released red-tailed hawks banded between 1957 and 2013. Furthermore, 23\% of these redtailed hawks were reported seen hit by vehicle or found on the roadside (suggesting vehicular impact), and $8 \%$ were reported injured a second time post-release. Many other rehabilitated red-tailed hawks were reported dead from shootings, electrocution, impacts with aircrafts and more, 
suggesting a high incidence of secondary anthropogenic mortality even after rehabilitation was deemed successful. Morishita et al. (1998) reported 58\% mortality in necropsied wild raptors due to physical trauma (e.g., car collisions), including red-tailed hawks $(n=109)$, which suggests that rehabilitated red-tailed hawks could suffer a similar fate if they are expected to function the same as wild red-tailed hawks after release. Additional research is needed to understand why such a high mortality rate (75\% in this study) of rehabilitated and released red-tailed hawks occurs in such a relatively short time frame post-release. Furthermore, obtaining knowledge on the fate of these rehabilitated and released individuals post-mortem is crucial toward evaluating the effectiveness of specific procedures that are used in rehabilitation on the likelihood of long-term survivorship.

Post-release survival and mortality information can be used as measures of rehabilitative success and is necessary towards future management decisions in the field of wildlife rehabilitation. Performing additional post-release necropsies, similar to those completed by Morishita et al. (1998), on rehabilitated and released individuals could establish if deaths are attributed to more natural (e.g., disease and famine) or unnatural causes (e.g., vehicular impact or incidental shootings). For example, one rehabilitated red-tailed hawk tracked via radio-telemetry in this study succumbed to mortality within one month of release, and after necropsy, results determined that the most likely cause of death was due to West Nile Virus (i.e., a natural mortality). In contrast, another rehabilitated red-tailed hawk in this study struck a window in a heavily urban area nine months after release and suffered a skull fracture (i.e., an anthropogenic-induced mortality). Rehabilitators and veterinarians could benefit from this type of information, especially if mortality is found to be attributed in any way to incomplete or ineffective rehabilitation (i.e., lack of available diagnostics available or medical inexperience). Theoretically, some rehabilitated birds may be released back into the wild population with unidentified problems or reduced fitness, rendering them incapable of escaping high-risk situations or making them more vulnerable to mortality after release. The combined results of this study help to supplement all current information known about rehabilitated red-tailed hawk survivability, adaptability and reintegrative success. However, future banding for all birds of prey released from rehabilitation, continued monitoring of individuals with similar case studies or unifying rehabilitation methods on a target species of interest or injury type are all examples of ways rehabilitators could aid in collecting supplemental data or testing new hypotheses to better understand post-release failures and successes, ultimately to improve wildlife rehabilitation practices.

\section{Conclusion}

This study used a relatively common bird of prey species, red-tailed hawks, to establish annual survival of post-release rehabilitated individuals. Overall, rehabilitated red-tailed hawk survival was lower than wild-caught and banded individuals nationally, with young birds being exceptionally vulnerable to early mortality. Annual survival of 13 individuals rehabilitated and released red-tailed hawks from DCHS was lower than either result caluclated from the national banding data.

Although the live-monitoring portion of this study was small-scale, it provided insight into mitigating factors that possibly affect post-release mortality. Results suggested a need for veterinary and conservation management actions to help maximize the future success of rehabilitated and released birds of prey for effective avian wildlife conservation. These include 1) support from the USGS Bird Banding Laboratory and associated state and federal wildlife agencies to require banding of all rehabilitated and released birds, with associated information on initial injury details, rehabilitation length and medical records, 2) state and/or federal level support to acquire additional post-release survival data, such as funding more known-fate tracking studies or performing formal necropsies upon retrieval of deceased rehabilitated individuals and 3) creation and adoption by the National Wildlife Rehabilitators Association (NWRA) and/or International Wildlife Rehabilitation Council (IWRC) of a formal model for known-fate, post-release monitoring efforts that can be replicated by other wildlife rehabilitators.

Increased participation in long-term monitoring efforts by rehabilitators will allow for greater, objective evaluation of rehabilitative success, not only for birds but also for all wildlife species in general. Other directed conservation efforts already aim to preserve wildlife species and populations through habitat restoration, habitat preservation or captive breeding programs, and they are continually being assessed with the hope of demonstrating positive outcomes (Parrish et al. 2003). The current study provides a potential framework for investigators to begin understanding if wildlife rehabilitation offers another avenue to accomplish similar goals. Additional research will be required to ascertain the usefulness of wildlife rehabilitation as a viable option for large-scale conservation efforts. If successful, wildlife rehabilitation may be considered a tool for large-scale conservation efforts in the future, especially as anthropogenic injury and mortality rates to wildlife increase. 


\section{Acknowledgements}

The authors thank the staff, interns and volunteers of Dane County Humane Society's Wildlife Center, NWRA, Wisconsin Wildlife Rehabilitators Association (WWRA), Wall Family Enterprises, International Crane Foundation (ICF), University of Wisconsin-Madison students, advisors and colleagues, Madison Audubon Society, and individual donors, friends and family.

\section{Conflict of interests}

The Author(s) declare(s) that they only conflicts of interest that could be considered are from a) the sources of research funding and b) J. E Sandberg's (past and present, continued) employment at Dane County Humane Society.

\section{Funding}

Funding for this research was provided in part by the following persons, granting opportunities, or organizations: National Wildlife Rehabilitator's Association (NWRA) Research Grant, Madison Audubon Society's Conservation Scholars Award, Wall Family Enterprises, Dane County Humane Society (ten private, restricted donations), and the University of Wisconsin-Madison Department of Zoology, Animal Sciences.

\section{References}

Amaral F.R., Sheldon F.H., Gamauf A., Haring E., Riesing M., Silveira L.F. \& Wajntal A. 2009. Patterns and processes of diversification in a widespread and ecologically diverse avian group, the buteonine hawks (Aves, Accipitridae). Molecular Phylogenetics and Evolution, 53(3), 703-715, doi: 10.1016/j.ympev.2009.07.020.

Battistone C. 2012. Ecology of red-tailed hawks in California in red-tailed hawks species account. Sacramento, CA: California Department of Fish and Game. Appendix F, pp. 1-17.

Bednarz J.C. \& James J.D. 1982. Nest-Sites and Habitat of Red-Shouldered and Red-Tailed Hawks in Iowa. The Wilson Bulletin, 94(1), 31-45, doi: 10.31274/rtd-180813-7490

Bildstein K.L. \& Peterjohn B.G. 2012. The future of banding in raptor science. Journal of Raptor Research, 46(1), 3-11, doi: 10.3356/JRR-10-110.1.

Bloom P.H. 2011. Vagrancy, natal dispersal and migrations of red-tailed and red-shouldered hawks banded in the pacific flyway. Ph.D. dissertation. Moscow, ID: University of Idaho.

Bloom P.H., Scott J.M., Papp J.M., Thomas S.E. \& Kidd J.W. 2011. Vagrant western red-shouldered hawks: origins, natal dispersal patterns, and survival. The Condor, 113(3), 538-546, doi: 10.1525/cond.2011.100052.

Bobowski M.M. 2013. The foraging behaviors and decision making strategies of over-wintering red-tailed hawks (Buteo jamaicensis) and American kestrels (Falco sparverius) in relations to prey density and patch site characteristics in Northeastern Arkansas. M.S. thesis. Jonesboro, AK: Arkansas State University.

Briggs C.W. 2007. Survival and nesting ecology of the Swainson's hawk in Butte Valley, CA. M.S. thesis. Reno, NV: University of Nevada Reno.

Brownie C., Anderson D.R., Burnham K.P. \& Robson D.S. 1985. Statistical inference from band recovery data: a handbook. 2nd edition. Resource publication 156. Washington, DC: U.S. Fish and Wildlife.

Brownie C., Hines J.E. \& Nichols J.D. 1986. Constant parameter capture-recapture models. Biometrics, 42, 561-574, doi: $10.2307 / 2531206$.

Buderman F.E., Diefenbach D.R., Casalena M.J., Rosenberry C.S. \& Wallingford B.D. 2014. Accounting for taggingto-harvest mortality in a Brownie tag-recovery model by incorporating radio-telemetry data. Ecology and Evolution, 4(8), 1439-1450, doi: 10.1002/ece3.1025.

Cherkassky L.M. 2011. Anthropogenic causes of wild bird mortality. Wildlife Rehabilitation Bulletin, 29(1), 1-11.

Cooch E. \& White G. 2012. A gentle introduction to Program Mark. Fort Collins, CO: Colorado State University.

Donohue K.C. \& Dufty A.M. 2006. Sex determination of red-tailed hawks (Buteo jamaicensis calurus) using DNA analysis and morphometrics. Journal of Field Ornithology, 77(1), 74-79, doi: 10.1111/j.1557-9263.2006.00003.x.

Duke G.E., Redig P.T. \& Jones W. 1981. Recoveries and resightings of released rehabilitated birds of prey. Journal of Raptor Research, 15(4), 97-107.

Edmunds, J. 2016. Home Range and Survival of Rehabilitated and Released Red-tailed Hawks (Buteo jamaicensis). M.S. thesis. Madison, WI: University of Wisconsin-Madison.

Fajardo I., Babiloni G. \& Miranda Y. 2000. Rehabilitated and wild barn owls (Tyto alba): dispersal, life expectancy and mortality in Spain. Biological Conservation, 94, 287-295, doi: 10.1016/S0006-3207(00)00003-3.

Fitch H.S., Swenson F. \& Tillotson D. 1946. Behavior and food habits of the Red-tailed Hawk. The Condor, 48(5), $205-$ 237, doi: 10.2307/1363939

Fridolfsson A.K. \& Ellegren H. 1999. A simple and universal method for molecular sexing of non-ratite birds. Journal of Avian Biology, 30, 116-121, doi: 10.2307/3677252.

Gates J.M. 1972. Red-tailed Hawks populations and ecology in East-Central Wisconsin. The Wilson Bulletin, 84(4), 421-433.

Griffin, C.R. 1985. Biology of the Hawaiian hawk (Buteos olitatius). Dissertation. University of Missouri, Columbia, USA.

Hamilton L.L., Zwank P.J. \& Olsen G.H. 1988. Movements and survival of released rehabilitated hawks. Journal of Raptor Research, 22(1), 22-26.

Heintzelman D.S. 2004. Hawks and owls of Eastern North America. Rutgers University Press. 
Henny C.J. \& Wight H.M. 1970. Population ecology and environmental pollution: red-tailed and Cooper's hawks. In Population ecology of migratory birds: a symposium. Pp. 229-249. Patuxent Wildlife Research Center.

Henny C.J. \& Wight H.M. 1972. Population ecology and environmental pollution: Red-tailed and Cooper's hawks. In Population ecology of migratory birds: a symposium. Pp. 229-250. Washington, DC: U.S. Department of the Interior Wildlife, Bureau of Sports Fisheries and Wildlife Research, Rep. 2.

Jackson A.M. 201 1. Survival estimates of white-tailed deer fawns at Fort Rucker, Alabama. M.S. thesis. Auburn, AL: Auburn University.

Johnson D.H. 1974. Estimating survival rates from banding of adult and juvenile birds. USGS Northern Prairie Wildlife Research Center. Paper 208. Accessed on the internet at http://digitalcommons.unl.edu/usgsnpwrc/208 on 3 April 2015

Johnson, S.J. 1975. Productivity of the red-tailed hawk in southwestern Montana. Auk, 92, 732-736, doi: 10.2307/ 4084784

Joosten S. \& Moore, A. (eds.) 2004. Principles of wildlife rehabilitation. 2nd edition. St. Cloud, MN: National Wildlife Rehabilitators Association.

Kenward R.E. 2001. A manual for wildlife radio tagging. London: Academic Press.

Kerlinger P. 2005. Survivor? Birder's World, 19(6), 58.

Krüger, O. \& Lindstrŏm J. 2001. Lifetime reproductive success in common buzzard (Buteo buteo): from individual variation to population demography. Oikos, 93(2), 260-273, doi: 10.1034/j.1600-0706.2001.930209.x

Lebreton J., Burnham K.P., Clobert J. \& Anderson D.R. 1992. Modeling survival and testing biological hypotheses using marked animals; a unified approach with case studies. Ecological Monographs, 62(1), 67-118, doi: 10.2307/2937171.

Lenth R.V. 1981. Robust measures of location for directional data. Technometrics, 23(1), 77-81, doi: 10.1080/00401706.1 981.10486240.

Luttich S.N., Keith L.B. \& Stephenson J.D. 1971. Population dynamics of the red-tailed hawk (Buteo jamaicensis) at Rochester, Alberta. The Auk, 88, 75-87, doi: 10.2307/4083962.

Martell M.S., Redig P., Nibe J. \& Buhl G. 1991. Survival and movements of released rehabilitated bald eagles. Journal of Raptor Research, 25(3), 72-76.

Martell M.S., Goggin J. \& Redig P.T. 2000. Assessing rehabilitation success of birds of prey through band returns. In Raptor biomedicine III. Pp. 327-334. Minneapolis, MN: University of Minnesota Press.

Miller E.A. (ed.) 2012. Minimum standards for wildlife rehabilitation. 4th edition. St. Cloud, MN: National Wildlife Rehabilitators Association. 116 pages

Molina-López R.A., Casal J. \& Darwich L. 2011. Causes of morbidity in wild raptor populations admitted at a wildlife rehabilitation centre in Spain from 1995-2007: a long term retrospective study. PLoS One, 6(9), e24603, doi: 10.1371/ journal.pone.0024603.
Morishita T.Y., Fullerton A.T., Lowenstine L.J., Gardner I.A. \& Brooks D.L. 1998. Morbidity and mortality in free-living raptorial birds of Northern California: a retrospective study, 1983-1994. Journal of Avian Medicine and Surgery, 12(2), 78-81.

Nasution M.D., Brownie C., Pollock K. \& Bennets R.E. 2001. Estimating survival from joint analysis of resighting and radiotelemetry capture recapture data for wild animals. Journal of Agricultural, Biological, and Environmental Statistics, 6(4), 461-478, doi: 10.1198/10857110152946839.

Newton I. 1979. Population ecology of birds of prey. Vermillion, SD: Buteo Books.

Parrish J.D., Braun D.P. \& Unnasch R.S. 2003. Are we conserving what we say we are? Measuring ecological integrity within protected areas. BioScience, 53(9), 851-860, doi: 10.1641/0006-3568(2003)053[0851:AWCWWS] 2.0.CO;2.

Perrins C.M. \& Birkhead T.R. 1983. Avian ecology. Glasgow: Blackie and Son Ltd. Distributed in USA by Chapman and Hall New York.

Pollock K.H., Winterstein S.R., Bunck C.M. \& Curtis P.D. 1989. Survival analysis in telemetry studies: the staggered entry design. The Journal of Wildife Management, 53(1), 7-15, doi: 10.2307/3801296.

Powell L.A. 2007. Approximating variance of demographic parameters using the delta method: a reference for avian biologists. The Condor, 109(4), 949-954, doi: 10.1093/ condor/109.4.949.

Punch P.I.P. 2001. A retrospective study of the success of medical and surgical treatment of wild Australian birds of prey. Australian Veterinary Journal, 79(11), 747-752, doi: 10.1111/j.1751-0813.2001.tb10890.x.

Reed E.T. 1976. Is your banding of any value? North American bird bander, 1(4), 178-179.

Schoenebeck C.W., Turco M., Fahrlander, R.M., Darveau, K.M. \& Freeman T.L. 2014. Sex and age group specific changes in body condition of red-tailed Hawks in central Nebraska. The Wilson Journal of Ornithology, 126(3), 575580, doi: 10.1676/13-131.1.

Seber G.A.F. 1970. Estimating time-specific survival and reporting rates for adult birds from band returns. Biometrika, 57(2), 313-318, doi: 10.1093/ biomet/57.2.313.

Sullivan J. 1995. Bubo virginianus in: fire effects information system. U.S. Department of Agriculture, Forest Service, Rocky Mountain Research Station, Fire Sciences Laboratory. Accessed on the internet at http://www.fs.fed.us/database/ feis/

Tristan T. 2010. The aging raptor. Veterinary Clinics of North America. Exotic Animal Practice, 13(1), 51-84, doi: 10.1016/j. cvex.2009.10.001.

USGS Bird Banding Laboratory. 2013. North American bird banding and band encounter data set. [Unpublished data file created and retrieved on 10/22/2013 and 11/19/2013]. Laurel, MD: Patuxent Wildlife Research Center.

White G.C. \& Burnham K.P. 1999. Program MARK: survival estimation from populations of marked 
animals. Bird Study Supplement, 46, 120-138, doi: 10.1080/ 00063659909477239.

White G.C., Burnham K.P. \& D.R. Anderson. 2001. Advanced features of Program Mark. In R. Field, R.J. Warren, H. Okarma \& P.R. Sievert (eds.): Wildlife, land, and people: priorities for the 21 st century. Proceedings of the
Second International Wildlife Management Congress, 368-377, Bethesda, MD: The Wildlife Society.

Woffinden, N.D. \& Murphy, J.R. (1989). Decline of a Ferruginous Hawk Population: A 20-Year Summary. The Journal of Wildlife Management, 53(4), 1127-1132, doi: $10.2307 / 3809619$ 